Studies 



\title{
Hunting down Emanuel Ringelblum. The Participation of the Polish Kriminalpolizei in the 'Final Solution of the Jewish Question'
}

\begin{abstract}
A policeman in pursuit of a criminal always judges the situation in accordance with the circumstances, acts as quickly as possible and decisively, and pursues the criminal persistently, until apprehension, regardless of the territory of his beat. ${ }^{1}$
\end{abstract}

When writing an article to a specialist periodical, such as Holocaust. Studies and Materials, addressed to a relatively small group of readers, the author usually does not need to write an introduction, which is necessary in other cases. He may assume a certain level of the readers' knowledge and move straight to the crux of the issue discussed. Unfortunately, in the case of the topic of this article, an extensive introduction is necessary for the simple reason that the subject matter of the occupation period operation of the Polish Criminal Police is one of the numerous blank spots on the map of the recent history of Poland. While the war-time history of the Polish uniformed services (beginning with the 'blue' police, through the volunteer and professional fire brigades, to the young guards from Baudienst) still calls for a thorough study, the activities of the Criminal Police remain practically unknown. In the several studies of the broadly defined German policy of terror one can occasionally find short comments on the Polish Criminal Police, usually limited to a few sentences. ${ }^{2}$ Readers of Marcin Wroński's whodunits, who followed the adventures of Police Commissioner Zygmunt Maciejewski, a Kripo officer and at the same time a good Pole fighting bandits and rapists in occupied Lublin, ${ }^{3}$ probably know the most about it.

1 "Surveillance instruction" from the Minister of Internal Affairs' ordinance of 4 January 1924 regarding the organization of the investigation offices, as cited in Andrzej Misiuk, Andrzej Pepłoński, Organizacja instytucji policyjnych w II Rzeczypospolitej, 1918-1926. Wybór źródeł i dokumentów (Szczytno: Wydawnictwo Wyższej Szkoły Policyjnej, 1994), p. 190.

${ }^{2}$ The only study where one can find a few pages about the Polish Criminal Police is Adam Hempel, Pogrobowcy klęski. Rzecz o policji „granatowej” w Generalnym Gubernatorstwie 19391945 (Warsaw: PWN, 1990), pp. 124-137.

${ }^{3}$ Marcin Wroński, A na imię jej będzie Aniela (Warsaw: W.A.B., 2011). 
Consequently, the role of Kripo officers in the extermination of the Polish Jews remains unknown, even though this topic is certainly worth investigating. In consequence, one should start at the beginning, that is, with the restoration of Polish independence, when the young Republic of Poland began to create its own police forces.

The Criminal Police (Policja Kryminalna) (known as the Investigation Service [Służba Śledcza]) was a specialised division of the pre-war State Police (Policja Państwowa, PP). ${ }^{4}$ Established in 1919, despite the administrative tensions and the jurisdictional conflict, it became an integral part of the police. The Investigation Service's regional and county branch offices were created at the local police stations during the first years after the restoration of independence. In certain cases, the 'criminal' policemen became subordinated to the local Polish Police structures, whereas in other cases they constituted a separate element, professionally subordinate to the higher authorities of the Investigation Service and partially independent of the local officers. Such a system was not only complicated, but also threatened to lead to the emancipation and independence of the Investigation Service, which was contrary to the wishes of the Warsaw headquarters. In 1922, the Investigation Services' structure was made uniform, with the local branch offices becoming subordinated to the heads of the district police departments. ${ }^{5}$ From then on the investigation offices became obliged to cooperate closely with the uniformed police, conduct investigations, supervise the network of informers, and run fingerprinting and photographic laboratories. The next restructuring took place after the May Coup d'État, when the Investigation Service assumed its final form, which survived until 1939. With its ordinance of 8 April 1927 the Ministry of Internal Affairs established the Investigation Service Headquarters, with 16 subordinate regional branch offices (established at the provincial police departments). Subordinate to them were district branch offices. The investigation offices were run by chiefs of police, who usually also performed the function of deputy provincial chiefs of the Polish Police. As a result of the liquidation of the political police in 1926, the Investigation Service took over most of its previous jurisdiction. As a result, the whole Service became informally divided into two main divisions: criminal and political. The tasks of the criminal police were realised in three spheres: (1) investigations in penal cases (political and criminal), (2) surveillance, that is, police intelligence service, and (3) keeping records on criminals. From the beginning of the 1930s the police began to vigorously bridge the division into the uniformed and investigation police, but these two divisions remained clearly separate until the end of the Second Republic of Poland. At the same time, transfer from the uniformed police to the criminal police was clearly regarded

\footnotetext{
${ }^{4}$ More about this topic see Andrzej Misiuk, Policja Państwowa, 1919-1939. Powstanie, organizacja, kierunki działania (Warsaw: Wydawnictwo Naukowe PWN, 1996), pp. 288-326.

${ }^{5}$ Ibidem, pp. 296-297.
} 
as promotion, with proposals of such transfers made exclusively to the best prepared and those most successful in their uniformed service, with appropriate education of the candidates also taken into consideration. For instance, when the Lublin criminal division was established, the provincial police chiefs ordered county chiefs of the Polish Police "to select four candidates for every county from among the lower rank policemen who [were] intellectually developed and fit for intelligence work [...]." Moreover, before starting their service in the criminal division the candidates had to complete various specialist courses.

As mentioned before, at the end of the 1930s the Investigation Office had two divisions: criminal and political. In Warsaw, the political division consisted of four brigades:

I - communist affairs; head - Sergeant Pawłowski, deputy - Staff Sergeant Smoczyński;

II - opinion; head - Lieutenant Józef Skrzypiński;

III - ethnic minorities; head - Grela, from 1937 sub-commissioner Jerzy Sachocki; IV - government security; head - Police Commissioner Stanisław Helle.

The criminal division of the Investigation Office consisted of the following brigades:

V - theft; head - Lieutenant Wacław Pluciński, deputy - Michał Olczyk. Brigade V dealt with more serious theft and break-ins such as bank, office, cashier's offices, and shop robberies;

VI - vice; until 1939 headed by Karolina Grabowska; during the occupation her position was taken by Lieutenant Franciszek Wochnik;

VII - flying, petty theft; head - Police Commissioner Seweryn Rosiński, then Second Lieutenant Podniesieński;

VIII - serious crime;

IX - forgery; deputy head - Adam Perkowski; during the war his position was taken by Władysław Paradowski;

$\mathrm{X}$ - banditry; head - Lieutenant Edward Czarski, who took command of the brigade a year before the war; during the war Czarski was transferred to the 'blue' police, where he was the head of the investigation department;

XI - Marshal's (commander-in-chief's) security.7

In 1933, the Investigation Service's headcount was 2,406 policemen, including 138 officers and 2,268 rank-and-file policemen. ${ }^{8}$ By 1938, the headcount increased to as many as 2,815 policemen, which amounted to approx. 4 per cent

${ }^{6}$ As cited in: Zbigniew Siemak, "Policja kryminalna II Rzeczypospolitej. Powstanie, organizacja, kadry i metody pracy," Zagadnienia Społeczne 1(1) (2014): 194.

${ }^{7}$ Archiwum Instytutu Pamięci Narodowej [Archive of the Institute of National Remembrance, later: AIPN], 0423/3402, pp. 35-44. The structure of the Investigation Office was recreated partly on the basis of the testimonies of Maria Dzięgielewska, the Office's secretary of many years, given during an investigation in 1950.

${ }^{8}$ Misiuk, Policja Państwowa..., p. 321. 
of the State Police headcount. ${ }^{9}$ On the eve of the war, the Polish criminal service had well trained personnel, relatively skilled at penetrating the criminal world and carrying out successful political surveillance. Those assets soon proved very important when the Germans decided to use that formation to implement their occupation policy.

\section{German Police in Occupied Poland ${ }^{10}$}

The police forces received an important role in the German plans of the invasion of Poland. In August 1939, 21 police battalions commanded by Kurt Daluege (Befehlshaber der Ordnungspolizei, BdO) joined the individual German armies to maintain order behind the front line. Furthermore, over 8,000 policemen were incorporated directly into the army to strengthen the ranks of the military gendarmerie. ${ }^{11} 6$ September marked the beginning of the activity of the Einsatzgruppen in Poland. Their objective was to use terror to introduce the German order on the freshly seized territories. Einsatzgruppe II B and Einsatzgruppe IV, which consisted of members of the Gestapo, SD, and Kripo, appeared in Warsaw as early as on 29 September 1939.12 Within several days after the capitulation of Warsaw, 120,000 Wehrmacht soldiers were stationed in Warsaw and its vicinity beside the aforementioned policemen..$^{13}$ On 4 October 1939, a ten-person team from the Berlin Kripo, commanded by Commissioners Henning and Bahr, arrived in Warsaw, following in the footsteps of the Wehrmacht soldiers and Einsatzgruppen. ${ }^{14}$ That was the beginning of the incredibly rapid

\footnotetext{
${ }^{9}$ Siemak, Policja kryminalna..., pp. 203. As of 1 January 1938, the Polish Police had 730 officers, including 153 in the investigation service, and 27,874 rank-and-file policemen (Hempel, Pogrobowcy klęski..., p. 29).

${ }^{10}$ More on the topic of the operation and organization of the German police in the General Government see Stanisław Biernacki, Jerzy Stoch, "Działania władz okupacyjnych (policji i administracji) w dystrykcie warszawskim przeciwko ruchowi oporu w latach 1939-1944," Najnowsze Dzieje Polski 10 (1966): 47-76; Lucjan Dobroszycki, Marek Getter, "Działanie urzędu komendanta policji i służby bezpieczeństwa w Radomiu w zakresie zwalczania ruchu oporu," Najnowsze Dzieje Polski 4 (1960): 23-61; Włodzimierz Borodziej, Terror i polityka. Policja niemiecka a polski ruch oporu w GG, 1939-1944 (Warsaw: PAX, 1985).

${ }^{11}$ Edward B. Westermann, “,Friend and Helper”: German Uniformed Police Operations in Poland and the General Government," The Journal of Military History vol. 58, 4 (October 1994): 645.

${ }^{12}$ Stanisław Biernacki, “Organizacja i metody działania policji hitlerowskiej w dystrykcie warszawskim," in Stan i perspektywy badań w zakresie zbrodni hitlerowskich (Warsaw, 1973), p. 194.

${ }^{13}$ Soldaten-Führer durch Warschau (Warsaw: Kommandantur Warschau, 1941), p. 16.

${ }^{14}$ Archiwum Państwowe m.st. Warszawy [State Archive of the Capital City of Warsaw, later: APW], Amt des Gouverneurs des Distrikts Warschau, Der SS- und Polizeiführer, file 155, pp. 13-14, Sprawozdanie dotyczące przejęcia policji obyczajowej [report on the takeover of the vice squad], Warsaw, 6 October 1939.
} 
subordination of the Polish police to the Germans. From the occupier's point of view that formation was to play a fundamental role in maintaining order in the seized territories.

In early November 1939, the Einsatzgruppen operating in Poland became transformed (or incorporated) into Security Police commands (Kommandeur der Sicherheitspolizei und des SD, KdS) or Order Police commands (Kommandeur der Ordnungpolizei, KdO). The KdS Office had several departments. The Gestapo and Kripo desks of our interest were incorporated into Department IV and Department $\mathrm{V}$ respectively. ${ }^{15}$

Aptly called Nebenland des Reiches by Hans Frank, the General Government ${ }^{16}$ was a police state in the strict meaning of this term. The terror machine model built in Germany from 1933 was transplanted with certain modifications onto the territory of the General Government. In the Reich, the police had two main divisions: the Security Police (Sicherheitspolizei, Sipo) and the Order Police (Ordnungspolizei, Orpo). Within the framework of the latter there were two formations: Schutzpolizei (Schupo), operating in towns, and the gendarmerie, serving mostly in rural areas and small towns. That division was introduced in the Reich and on the Polish territories incorporated into the Reich (eingegliederte Ostgebiete). That structure was retained in the General Government, but with major alterations to adapt it to the local conditions. Those changes regarded predominantly the manner of utilising the pre-war Polish police forces, necessary to cope with the wartime chaos and restore public safety. The almost five thousand German Orpo policemen, stationed in the General Government during the first months of the occupation, could not perform their tasks due to the hostility of the local population and lack of language skills.

On 30 October 1939, the General Government's Higher SS and Police Leader Friedrich Wilhelm Krüger issued an ordinance calling on all Polish policemen to begin their service in the reorganised police and threatening severe punishment of the disobedient. ${ }^{17}$ Krüger's ordinance brought the expected results and as early as in January 1940 the Polish Police headcount was over 10,000, including 1,173 criminal policemen. ${ }^{18}$ After vetting and removal of the majority of higher rank officers, a new Polish police was established. Called the 'blue' police from the colour of the uniforms, it was subordinated to KdO but retained the pre-war internal structures and was based on its previous functionaries. The Polish Police

\footnotetext{
${ }^{15}$ During the first years of the occupation, the KdS structure looked slightly different, but it took its final shape with the reorganization in May 1941 (see Biernacki, Organizacja i metody działania policji..., p. 196).

${ }^{16}$ In the original text, the author uses the name "Generalna Gubernia" instead of "Generalne Gubernatorstwo" (General Government) to retain the atmosphere of those times, as the former name was in use then.

17 „Verordnungsblatt des Generalgouverneurs” (VBIGG) 1939, p. 16.

${ }^{18}$ Archiwum Akt Nowych [Archive of Modern Records, later: AAN], Government of the General Government, file 641, pp. 15-19, as cited in: Hempel, Pogrobowcy klęski..., pp. 38-39.
} 
of the General Government was officially and finally established on 17 December 1939 as per an appropriate ordinance of Governor General Hans Frank.

\section{Polish Kriminalpolizei (Polish Criminal Police)}

Despite major changes, the Polish uniformed police retained its pre-war character, whereas the fate of the Investigative Service took a different course. With the end of October 1939, the Polish secret police was excluded from the Polish Police structures, incorporated into Kripo as the Polish Criminal Police (Polnische Kriminalpolizei), and subordinated to the German command. The position of the Warsaw Kripo chief, and at the same time the superior of the Polish agents, was assumed by government councillor (Regierungsrat) SS-Sturmbannführer Harry Geisler, with criminal councillor (Kriminalrat) Erich Spruch as his deputy. ${ }^{19}$ In the General Government, Kriminalpolizei, a part of the KdS structures, was divided into the following desks:

V A - Polish employees affairs;

V B - criminal executive service;

$\mathrm{V} \mathrm{C}$ - surveillance and law enforcement service;

V D - technical investigation service. ${ }^{20}$

Thus, in the autumn of 1939, the Polish police investigators became employees of the German Security Police (Sipo). Mutually independent Criminal Police Directorates (Dyrekcja Policji Kryminalnej, DPK) were established in the capital city of each of the General Government's four districts (Kraków, Radom, Lublin, and Warsaw). In August 1941, after the district of Galicia became incorporated into the General Government, the fifth directorate was created in Lvov. Simultaneously, investigation sections were established in the individual police stations. Though subordinate to the DPK, they were organisationally separate from the uniformed police. In Warsaw, Kripo was established in the prison at Daniłowiczowska Street 7 and at Al. Ujazdowskie Street 90, with its subordinate posts in the Warsaw District located in Ostrów Mazowiecka, Garwolin, Skierniewice, Łowicz, Siedlce, Grójec, Mińsk Mazowiecki, Pruszków, and Sokołów Podlaski. ${ }^{21}$ Some Kripo stations had a dual function, as they were

${ }^{19}$ AIPN, GK 164/3754, pp. 3-4. Other commanders of the Warsaw Kripo: Kriminalrat Strunz [Inspektion - Inspectorate], Kriminalkommissar - van Look [Inspektion]; Kriminalkommissar - Doctor Rogensack [Inspektion]; Kriminalkommissar Georg Richter, Division Head [Kommissariat Leiter]; Kriminalkommissar Horst Corfei, and Kriminalinspektor Friedrich Geisler.

${ }^{20}$ Stanisław Biernacki, Okupant a polski ruch oporu. Władze hitlerowskie w walce z ruchem oporu w dystrykcie warszawskim, 1939-1944 (Warsaw: Główna Komisja Badania Zbrodni Hitlerowskich w Polsce, 1989), pp. 24-25.

${ }^{21}$ Interesting correspondence from the Kripo branches outside Warsaw can be found in the files of the German Court (Deutsches Gericht) fond in the APW, for example, files 1207/5185, $1207 / 5384,1207 / 5184$, and $1207 / 5151$. 
sometimes also border police posts (Grenzpolizeikommissariat, Greko). ${ }^{22}$ It should be noted that in the localities without Gestapo stations their role was taken over by Kripo offices. The two organisations cooperated closely with each other, with the Gestapo having an absolutely unlimited access to the records of the Polish Criminal Police.

\section{Warsaw Criminal Police Directorate}

As early as before the end of 1939, the Warsaw Investigation Office became divided into seven Divisions (not to be confused with the Polish police stations): I - banditry; established on the basis of former Brigade X of the Investigation Office; headed by Seweryn Rosiński, later chief of the Criminal Police Directorate, with Second Lieutenant Władysław Sawicki as the deputy;

II - theft (former Brigade V); head - Michał Olczyk, deputy - Wacław Pluciński; III - spontaneous theft (former Brigade VII); head - Second Lieutenant Józef Podniesieński;

IV - forgery (former Brigade IX);

$\mathrm{V}$ - vice (former Brigade VI);

VI - tracing (former Registration Bureau);

VII - identity establishment, Central Administrative Office and Supervision. ${ }^{23}$

The first head of the Warsaw Criminal Police Directorate (official title: liaison officer) was Lieutenant Colonel Stanisław Wasilewski, who held that position until 11 June 1942, when he quit the service and went into hiding from the Germans. In 1943, Wasilewski 'Rogala' became a member of the senior leadership of the Security Department of the Warsaw branch of the Office of the Delegate of the Government in Exile (Delegatura Rzadu na Warszawę). ${ }^{24}$ At the same time, he was one of the creators of the National Security Corps (Państwowy Korpus Bezpieczeństwa, $\mathrm{PKB}$ ), that is, the underground police apparatus, which became a part of the structures of the Office of the Delegate of the Government in Exile. ${ }^{25}$ After Wasilewski, the position of the Criminal Police Directorate Chief

${ }^{22}$ Derzhavnyy Arkhiv L'vivs'koyi Oblasti [Lviv Oblast State Archive, later: DALO], Sondergericht Lemberg, file 450, Drohobycz-Borysław station, investigation regarding the suicidal death of Ajzyk Szlezinger, p. 3.

${ }^{23}$ AIPN, 0423/3402, pp. 35-44, 227-229, and 251-257.

${ }^{24}$ Waldemar Grabowski, Polska tajna administracja cywilna, 1940-1945 (Warsaw: IPN, 2003), p. 202.

${ }^{25}$ Hempel, Pogrobowcy klęski..., pp. 220-221. More on the topic of the organization and structures of the PKB in Grabowski, Polska tajna administracja cywilna..., pp. 343-345. In June or July 1944, the DKP head secretary Maria Dzięgielewska gave Wasilewski a list of 600-700 Polish Criminal Police employees with their ranks and positions. Wasilewski was to examine their stance and prepare evaluations from the point of view of the Polish Underground State. Together with Lieutenant Pluciński (anti-theft Division Head) and Dzięgielewska, Wasilewski initially divided the Warsaw agents into three groups: (1) those who had retained their 
was assumed by Lieutenant Colonel Chmaj. After his death from a heart attack in April 1943, the position of the Polish Kripo head was assumed by Seweryn Rosiński, who was at the same time the director of Division $\mathrm{I}^{26}$

Little is known about the personnel shifts within the Polish Criminal Police during the initial months after the defeat of Poland. In Warsaw, which is the object of this study and where a relative abundance of source materials have survived, most policemen continued to perform their previous tasks after swift vetting. The counterintelligence, that is, Brigades I-IV of the prewar Investigation Office, constituted an exception for obvious reasons. Those brigades were disbanded by the Germans; some of the agents were arrested, while others were transferred to the newly established criminal divisions. For instance, Antoni Haar and Wincenty Wilczyński, who before the war conducted anti-communist activity, became incorporated into Division I. Similarly, Platoon Leader Kazimierz Duchiński and Bronisław Chudzikowski were transferred from the Counterintelligence to Division II, while Józef Skrzypiński, pre-war head of Brigade II, was transferred to Division VI (vice).

The organisational restructuring was accompanied by important personnel changes caused by the arrival of the policemen delegated from the Reich to Warsaw to 'work in the East.' At the turn of 1939 and 1940, a certain number of Germans appeared in the Polish Criminal Police to supervise the Polish policemen. One of the new German employees was Criminal Commissioner SS-Hauptsturmführer Wilhelm Tewes, who was transferred to work in the Warsaw Kripo in early $1940 .{ }^{27}$ According to Tewes' post-war testimony, there were approx. 50 German and 700 Polish policemen in the local Kripo, while the division to which he was delegated had 4 German and 50 Polish employees. ${ }^{28}$ With time, the German policemen delegated from the Reich to work in the General Government were joined by locally recruited Volksdeutsches. Kazimierz Garbowski, a young Pole hired to work in the Polish Criminal Police at the end

\footnotetext{
"strong political and moral backbone," (2) those who had retained only their strong political backbone, but "have wavered morally," and (3) those employees who closely cooperated with the Germans and took advantage of their position to make a profit (AIPN, 0423/3402, Przesłuchanie Stanisława Wasilewskiego [interrogation of Stanisław Wasilewski], 29 December 1949, pp. 85-87).

${ }^{26}$ AIPN, 0423/3402, Przesłuchanie Marii Dzięgielewskiej [interrogation of Maria Dzięgielewska], 30 December 1949, pp. 226-227.

${ }^{27}$ AIPN, GK 164/3754, Protokół przesłuchania Wilhelma Tewesa przez angielskie władze okupacyjne w Niemczech [typescript of the interrogation of Wilhelm Tewes by the English occupation authorities in Germany], 23 August 1946.

${ }^{28}$ Initially, Tewes worked at the station on Teatralny Square; later, in 1943 he was transferred to the one on Al. Ujazdowskie Street. In his testimony Tewes stressed the following: "my professional activity was limited only to the territory of the city of Warsaw [...]. The German policemen dealt exclusively with the crimes harmful to the interest of the German nation; all the remaining cases were in the jurisdiction of the Polish policemen" (AIPN, GK 164/3754, p. 3).
} 
of the occupation, mentioned them in his testimony: "In March 1944 I applied for work to the German Kriminalpolizei, because the railway paid very little and I could not 'get by', while my friends encouraged me [to apply] because Kripo paid more. In mid-March, Kripo hired me for a probation period of 18 months. The Germans were directors and chiefs, while the rest were Poles from the prewar criminal police or Volksdeutsches, so there was one Volksdeutsch for every four Poles, whom he supervised."29

Despite the personnel changes ${ }^{30}$ and in a significantly altered form, the Polish Criminal Police began to carry out its statutory tasks as early as before the end of 1939. Theoretically, in accordance with Sipo's bylaws, the Polish Criminal Police was to focus on investigating common crime. But in fact, the Polish Kripo became one of the key elements of the Nazi terror apparatus, and during the next years of the occupation an important area of its activity became hunting for the Jewish survivors who had managed to avoid deportation to death camps and who were trying to survive on the 'Aryan' side.

\section{Kriegsfahndungkommando - 'Wartime Tracing' Kommando}

We are star searchers [...]. We look for yellow stars... ${ }^{31}$

The particularly intensive hunt for the Jews hiding in Warsaw and its vicinity began in late April 1943, that is, with the uprising in the ghetto. Between July and September 1942, the thousands of escapees who had crossed to the 'Aryan' side during the great deportation campaign were joined by hundreds of new escapees from the burning ghetto, which was being liquidated. A stifling, horrifying period began for the Jewish survivors. Finding a new hideout was becoming increasingly difficult, while the Polish friends and rescuers were growing more and more frightened every day. Teams of blackmailers were combing the city in search of new victims, and the thick network of informers facilitated the work of various police forces: undercover, uniformed, Polish, and German. That was when the Criminal Police Directorate on Al. Ujazdowskie Street prepared a plan to establish a specialised cell, whose main objective would be to track

${ }^{29}$ AIPN, 0423/4447, Przesłuchanie Kazimierza Garbowskiego [interrogation of Kazimierz Garbowski], 26 January 1950, pp. 14-15.

${ }^{30}$ The policemen from the Kraków Criminal Police were also in a relatively stable situation. Before the war, the Kraków investigation service had 120 policemen, including 9 officers and 111 rank-and-file policemen. Even though the personnel composition changed a little during the occupation, the changes were not radical. In 1943, the Kraków Kripo still employed more than 100 policemen, only ten of whom were German. The rest were pre-war Polish policemen from the local Investigation Office (Bundesarchiv Ludwigsburg [Federal Archives in Ludwigsburg, later: BAL], B162/2149, p. 363).

${ }^{31}$ Marek Hłasko, "Szukając gwiazd," in idem, Opowiadania (Paris: Instytut Literacki, 1963), as cited in Zagłada Żydów. Studia i Materiały 4 (2008): 417. 
down and arrest the hiding Jews. So far, tracking down Jews was among the professional duties of various organisations: the 'blue' police, Gestapo, Order Police, Schupo, gendarmerie, and criminal police. The establishment of the cell dealing exclusively with hunting the Jews might have meant that the German authorities regarded the situation in Warsaw as worrying, and that the hunt for the Jews was deemed a priority.

Besides, formation of a special police unit to hunt Jews was not an original idea of the security authorities in the General Government. In France, a 'storm' group operating within the framework of the Paris Police Prefecture from the beginning of 1943 tracked down the Jews who had managed to avoid Operation Vent Printenier (spring wind), that is, the mass arrests conducted in the summer of 1942. Members of that unit were called les mangeurs des Juifs (Jew eaters) by fellow policemen. Other police groups 'for special tasks' operated within the framework of the office named Commissariat Général aux Questions Juives, while others were a part of Milice française, which collaborated with the Germans. Apart from those fundamentally French institutions, there were also groups directly dependent on the Gestapo and Kripo ${ }^{32}$ and acting on their direction. The situation was similar in Holland, where between 1943 and 1944 there was a very vigorously operating police group, called 'Henneick's column', to which at least several thousand of the Amsterdam Jews had fallen its victims. The policemen and volunteers from Henneick's column based their operational tactics to a large extent on incriminating letters and informers, which proved as uncomplicated as it was effective. ${ }^{33}$ The situation was no different in the East. During the last several years scholars have begun to describe the operation of the special police and collaboration formations that operated in Ukraine and Belarus. ${ }^{34}$ In the light of the historians' findings it has become clear that in all of the occupied countries there were special detachments and units whose main objective was to apprehend the hiding Jews. Though the inspiration and motivation for those actions are debatable - after the war some of their participants justified themselves with ideology, religion, a desire to obtain loot, or any possible combination of these factors - one cannot deny the existence of

${ }^{32}$ More on this topic in Jean-Marc Berlière, Les policiers français sous l'occupation (Paris: Perrin, 2001); Laurent Joly, L'antisémitisme de bureau. Enquête au coeur de la préfecture de Police de Paris et du commissariat général aux Questions juives, 1940-1944 (Paris: Grasset, 2011); Tal Bruttman, La logique des bourreaux, 1943-1944 (Paris: Hachette, 2003).

${ }^{33}$ Ad van Liempt, Hitler's Bounty Hunters. The Betrayal of the Jews (Oxford-New York: Berg, 2005).

${ }^{34}$ Martin Dean, Collaboration in the Holocaust: Crimes of the Local Police in Belorussia and Ukraine, 1941-1944 (New York: St. Martin's Press and USHMM, 2000); John-Paul Himka, "The Lviv Pogrom of 1941: The Germans, Ukrainian Nationalists, and the Carnival Crowd," Canadian Slavonic Papers, vol. 53, 2-4, June-December 2011, pp. 209-224; Gabriel N. Finder, Alexander V. Prusin, "Collaboration in Eastern Galicia: The Ukrainian police and the Holocaust," East European Jewish Affairs vol. 34, 2 (2004): 95-118. 
those extensive police structures intended for the ultimate extermination of the European Jews. Consequently, there is nothing extraordinary about the wartime police detachments established specifically to hunt Jews. The only unusual thing is the silence concerning Poles engaged in those anti-Jewish efforts.

The plan to establish a special police unit was implemented at the end of the summer of 1943. The new section of the Polish Criminal Police was euphemistically called Kriegsfahndungkommando (Wartime Tracing Kommando) ${ }^{35}$ According to one testimony, the door to the room of its agents had a highly telling doorplate - Oberstreifkommando, ${ }^{36}$ while the Polish employees of the Warsaw Kripo referred to the unit as simply the 'Jewish desk'. Little is known about the creation, operation mode, or the personnel of the newly established Judenreferat. According to the sparse mentions during the post-war investigations and the occupation-period notes of the Home Army intelligence (Armia Krajowa, AK), the Kreigsfahndungskommando was a mixed unit aside from about a dozen undercover police from the Polish Criminal Police, transferred from various police stations, there were several German policemen, several Volksdeutsches, and two Ukrainians.

The Kriegsfahndung section was assigned to special tasks, so it was not a part of any of the seven divisions of the Polish Criminal Police Directorate, but it was directly subordinate to the German board of the Criminal Police Directorate. The Kriegsfahndungkommando was headed by Criminal Commissioner SS-Untersturmführer Werner Balhause. Little is known about Balhause (a.k.a. Ballhause and Balhausen). ${ }^{37}$ Before his transfer to Warsaw, he was a Kripo employee in Ostrowiec Świętokrzyski, where he was purportedly co-responsible for the liquidation of the local ghetto. He joined the Warsaw Kripo probably in the first half of 1943 and became the German supervisor of Divisions II and III (theft) of the Polish Criminal Police in the Warsaw Criminal Police Directorate. According to the report on the surveillance of the 'blue' police carried out by the underground, working in Warsaw purportedly brought him considerable

${ }^{35}$ AIPN, GK 317/248, Przesłuchanie Marii Dzięgielewskiej [interrogation of Maria Dzięgielewska], 3 January 1950, pp. 52-53.

${ }^{36}$ Oberstreifkommando (German) - Main Roundup Kommando. AIPN, GK 317/248, Zeznanie świadka Bronisława Chudzikowskiego [witness Bronisław Chudzikowski's testimony], 13 January 1950 , pp. 57-57v.

${ }^{37}$ An investigation against Balhause was launched in Hamburg in 1967: Zentrale Stelle der Landesjustizverwaltungen zur Aufklärung nationalsozialistischer Verbrechen in Ludwigsburg (Central Office for Investigation of Nazi Crimes in Ludwigsburg), 206 AR-Z 23/64, State Public Prosecutor's Office in Hamburg, 147 Js 34/65, Liquidation of the ghetto in Ostrowiec Świętokrzyski and other places. Born on 27 March 1903 in Berlin, Werner Balhause served in KdS-ADS in Ostrowiec Świętokrzyski in the rank of a criminal commissioner (for instance, in Department V of KdS Warschau). The files are stored at the Hamburg Public Prosecutor's Office. So far I have been unable to access these materials. I am grateful to Doctor Andrea Löw from the Munich Institut für Zeitgeschichte for this information. 
profits. A fragment of the report's entry of 19 January 1944 reads: "a number of the German employees of the Kripo directorate (Balhausen, Nusperling, and others) are sending looted furniture and valuable objects to the Reich or they store them in the residential buildings occupied by the army, for instance, on Rozbrat Street." ${ }^{38}$

Balhause employed volunteer policemen in the new section, most of them highly experienced in tracing Jews. It was no accident that he brought over two agents from Division II, who had been pre-war undercover policemen who had an extensive network of informers in the city. Balhause's deputy in the Judenreferat was Kriminalsekretär Schuhardt, while the remaining German functionaries were Kriminalassistent Henel (or Henkel) and Bömisch, a policeman from Silesia. The Germans from the Kriegsfahndungskommando were allocated a room in the Kripo office, while their Polish subordinates and co-workers occupied another one. ${ }^{39}$ Initially, the director of the Polish section was Wacław Stroka. After his death in early 1944 in an accidental fusillade on Krochmalna Street, his position was probably taken by Zygmunt Głowacki, a Division II agent. Agents Jan Putrycz (a.k.a. Puszyn) and Władysław Nowiński also worked in that division, with the latter transferred from the anti-theft division, as Głowacki. Among the desk employees there were also policemen Władysław Olszewski, Sybilski, and two junior policemen: Jerzy Gzel (a.k.a. Gezell) was Paluchowski. The section's first translator was a Pole by the name of Adamiec. After his death in January 1944 during a fusillade in Mińsk Mazowiecki, his position was assigned to Volksdeutsch Bąk. The Jewish desk's secretary was Janina (or Irena) Oleszuk, a pre-war employee of the Office. Agent Leszek Tuszpiński, who acted as a liaison between the Polish and the German personnel, also played an important role. The daily operation of the Jewish desk was based predominantly on close cooperation with a network of informers. Each agent ran his own agents, who penetrated various groups of the population or various quarters of Warsaw. A secretary of the Warsaw Criminal Police Directorate, who was in daily contact with the policemen, mentioned "a number of informers" working for the Kriegsfahndungkommando. ${ }^{40}$ It is also known that one of the policemen "was in contact with the informers, who kept calling him from the city." ${ }^{\prime 1}$ The aforementioned Sergeant Głowacki was in charge of ten

\footnotetext{
${ }^{38}$ AAN, Delegatura Rządu na Kraj [Office of the Delegate of the Government in Exile], 202/II-44, „Kronika wydarzeń na terenie m.st. Warszawy od 1 sierpnia 1942 do 30 kwietnia 1944 r." [chronicle of events in the territory of the capital city of Warsaw from 1 August 1942 to 30 April 1944).

${ }^{39}$ In both these cases the list of the officers is incomplete, as I have managed to confirm only some of the surnames.

${ }^{40}$ AIPN, GK 317/248, Przesłuchanie Marii Dzięgielewskiej [interrogation of Maria Dzięgielewska], 3 January 1950, p. $52 \mathrm{v}$.

${ }^{41}$ Ibidem, Przesłuchanie Władysława Nowińskiego [interrogation of Władysław Nowiński, 24 Fabruary 1950, pp. 14-15.
} 
informers and cooperated with Jan Łakiński, ${ }^{42}$ a special commissions agent, who was soon executed as per a sentence passed by the underground. ${ }^{43}$ Anonymous incriminating letters sent to the police and then verified by Balhause also played an important role in the operation of the Jewish desk. ${ }^{44}$ Employees were transferred to work in the Jewish desk upon invitation or at their own request. Starting employment in the new section was conducive to establishing closer contacts with the German supervisors, which could prove very helpful in one's professional carrier. Some of the policemen were even promoted to officer ranks, and one of the volunteers, a pre-war Platoon Leader from the anti-theft brigade, was promoted in the Judenreferat to Senior Sergeant. It should be added that the Polish agents employed in the Wartime Tracing Kommando had undergone solid training. Back in 1941, two of them completed special three-week courses in penal law, investigation service, and investigation techniques. ${ }^{45}$ Those courses were organised in Rabka, in a special SS and SD school for Poles, conducted by Junior Inspector Stano, the head of the Investigation Department from Kraków. ${ }^{46}$

As far as the methods of the investigation work are concerned, all that is known is that the agents went on missions "in patrols," usually in groups of two or three policemen. Karol Frankowski, a policeman from the anti-theft brigade, testified the following: "The desk [Kriegsfahndungskommando] was completely subordinate to the Germans. The desk's objective was to [carry out] special surveillance and arrests. I saw with my own eyes Zygmunt G. [one of the policemen - J.G.] bring those arrested to the Office. He always set out on those missions in the company of two individuals. He worked in Warsaw, mostly on the territory of the ghetto. Sometimes they would go on those missions by car. There was talk that that desk was making a handsome profit. It had the worst opinion possible [...]; the people assigned to that desk were particularly trusted ones; once, one of the employees committed suicide because he was unable to take it psychically." ${ }^{\prime 7}$ Sometimes a German would lead the patrol, but most of the time

42 "I know that Głowacki worked in Kripo in the anti-Jewish section. Łukiński, who also worked there, lived in the same building as I did. he was executed by the underground" (AIPN, GK 317/247, Protokół rozprawy głównej, Zeznanie Bolesława Epelbauma [typescript of the main hearing, testimony of Bolesław Epelbaum], p. 91).

${ }^{43}$ AIPN, GK 317/248, Przesłuchanie Zygmunta Głowackiego [interrogation of Zygmunt Głowacki], 14 January 1950, pp. 21-22. During the interrogation Głowacki gave the personal details of one of those informers, Mieczysław Jankowski 'Borys', who "spoke German and English fluently, and also claimed to speak French."

${ }^{44}$ Ibidem, Przesłuchanie Władysława Nowińskiego [interrogation of Władysław Nowiński], 13 March 1940, p. 48v.

${ }^{45}$ Ibidem, Przesłuchanie Zygmunta Głowackiego [interrogation of Zygmunt Głowacki], 31 January 1950 , pp. 29-30.

${ }^{46}$ A reference to the Security Police and Security Service School (Führerschule der Sicherheitspolizei und des SD) established at the turn of 1939 and 1940. The school had two sections: German and Polish.

${ }^{47}$ AIPN, GK $317 / 248$, pp. 55-55v. 
the patrols were commanded by a Polish criminal policeman. The patrols were sent to the addresses, which had already been under surveillance where some Jews were supposedly staying. After the Jews were arrested, they were escorted to the Criminal Police Directorate, where they were interrogated. According to one of the testimonies, "[A]gent G. treated the apprehended harshly. [...] [H]e interrogated the Jews, treating them harshly and shouting." ${ }^{\prime 8}$ After the initial interrogation, the victims were transported to the Gestapo on Szucha Avenue or were taken to Pawiak Prison. All employees of the Jewish desk occasionally took part in the escorting of the apprehended Jews to the next place of torment. As one of the interrogated policemen claimed, "the Jews were purportedly taken from the Gestapo to the concentration camps in Treblinka, Oświęcim, or other ones." $^{49}$

In fact, in 1943 and 1944, the Jews were transported to the nearby ghetto ruins, where the Germans conducted mass executions, which the underground press reported on every couple of days. It should be noted that the captured Jews were escorted to the Tracing Kommando offices also by 'blue' policemen and criminal policemen from other police stations.

It is difficult to say anything specific about the first months of the operation of the Jewish section of Kripo, as only shreds of information have survived in the underground reports and post-war testimonies. Besides, it remains unknown where the capture of Jews on the policemen's own initiative ended and where actions within the framework of the official duties began. But it is certain that one of the first operations of the Kriegsfahndungskommando connected with the Jews, though not directly, was the trip to Treblinka made in the autumn of 1943 by several policemen, led by Balhause. The objective was to investigate the robbery of the local inhabitants committed by the Ukrainian camp guards. It remains uncertain whether the Kripo policemen visited the death camp, which was being liquidated, or the nearby AEL Treblinka I labour camp. Anyhow, several photographs have survived from that trip. One of them depicts a Polish policeman from the Tracing Kommando against the background of a police car, holding a machine gun.

In the late autumn of 1943 the Kriegsfahndungskommando developed its own operation style and began to arrest Jews both on its own initiative and upon orders from other institutions. According to one of the agents, who obviously tried to belittle the scale of the repressions in his post-war testimonies, "the arrests of the Jews were conducted frequently, on average once or twice

${ }^{48}$ Ibidem, Przesłuchanie Władysława Nowińskiego [interrogation of Władysław Nowiński], 24 Fabruary 1950, pp. 14-15.

${ }^{49}$ Ibidem, Przesłuchanie Władysława Nowińskiego [interrogation of Władysław Nowiński], 2 March 1950, pp. 45-45v. 
a week." ${ }^{0}$ The apprehensions took place usually in the apartments where the Jews were hiding. Today, the shortage of sources prevents one from determining or even estimating the scale of the anti-Jewish operation of the Warsaw Kripo. The vast majority of the victims of the Polish policemen shall forever remain anonymous; their ashes lost forever in the ghetto ruins. Thus it is all the more crucial to recall the few surnames, addresses, and dates, which can be extracted from the documents and which enable the historian to bring at least a few victims back from anonymity and oblivion.

In January 1944, two agents from the section, accompanied by translator Adamiec, went "to a street [in the Warsaw] Old Town, between Podwale Street and the Old Town Square." One of them testified the following: "[I]n an apartment on the third floor, we found two elderly women of Jewish nationality. They were probably mother and daughter. We apprehended them both and escorted them to the Directorate. ${ }^{51}$ After some time, translator Adamiec returned to the empty apartment to take the bed linen and underwear, which were then distributed among the policemen from the station. The two Jewish women had been hiding using false papers, but during the interrogation they confessed to the Kripo agents that their real surname was Fajans. A little later, in the early spring of 1944 the agents appeared on Twarda Street, between Złota and Pańska streets, where a 20-year-old Jewish female subtenant was living. She was arrested, while her Polish landlords avoided the unpleasant consequences, probably using the popular argument that they had sublet the room to the Jewish woman "in good faith," without knowing her actual origin. "No items were taken," added the Kripo agent in his defence. Another arrest took place in the Powiśle quarter, where the Kriegsfahndungkommando found "an elderly Jewish woman living alone in destitute conditions." Perhaps that was why also that time "no items were taken," as the former policemen assured. In a residential building on Hoża, Wilcza, or Wspólna Street, the agents apprehended a Jewish man, approx. 30 years of age. The same as the other Jews, he was first escorted to the Criminal Police Directorate. Another elderly Jewish lady was apprehended in a villa in the Żoliborz quarter. Purportedly nothing happened to her Polish landlords, as in the previous case. But it is difficult to believe this part of the testimony. For the point of view of the Kripo policemen interrogated after the war it was apparently easier to confess to apprehending Jews than to arresting Poles or stealing the victims' property, in the spring of 1944, another Jewish woman was apprehended in a residential building on the corner of Puławska and Rakowiecka streets, an entire Jewish family was dragged out from a building on Wronia Street, and at some other time a Kripo patrol arrested Jews in a building on one of the streets branching off from Belwederska Street.

${ }^{50}$ AIPN, GK 317/248, Przesłuchanie Zygmunta Głowackiego [interrogation of Zygmunt Głowacki], 9 February 1950, pp. 31-32.

${ }^{51}$ Ibidem, pp. 34-34v. 
The members of the Kommando sometimes also went on expeditions outside of Warsaw. In May 1944, policemen Bömisch, Tuszyński, Nowiński, Henkel, Głowacki, and Gsell went to Świder, where a Jewish family was thought to be hiding. The trip did not bring the expected results, but there is no doubt that the operation, which the Kripo agents remembered best, was the discovery and liquidation of the 'Krysia' shelter.

\section{The Polish Criminal Police in Pursuit of Emanuel Ringelblum. 7 March 1944, the 'Krysia' Bunker}

For informative and intelligence purposes it is necessary that the agents speak the national and foreign languages and also know the Jewish jargon. ${ }^{52}$

One of the Jews hiding in Warsaw was Emanuel Ringelblum, the founder of the Oneg Shabbat underground archive team and a Warsaw ghetto chronicler, who spent the final months of his life in the 'Krysia' bunker at Grójecka Street 81. The bunker was dug underneath gardener Mieczysław Wolski's greenhouse, on the outskirts of Warsaw, where the suburbs of southern Ochota were gradually becoming the countryside. The hideout was exceptional as about 30 people were hiding there together with Ringelblum, including his wife Judyta and 15-year-old son Uri. In the 1944 Warsaw, such a bunker was something totally unique. The literature on hiding and rescuing does not mention an equally large hideout whose residents managed to survive for so long. The chroniclers of the uprising in the ghetto did mention large bunkers, some of which sheltered as many as a few hundred people, but all those shelters were discovered and destroyed by the Germans before the end of May 1943, and of course they were located in the ghetto. On the 'Aryan' side, the Jews were hiding in small groups, sometimes in families, sometimes individually. As far as the hiding Jews are concerned, the 'Krysia' bunker was indeed a unique hideout. This is what Emanuel Ringelblum wrote about it: "[A]t the helm of the shelter is 'the boss', Mr. Władysław M., ${ }^{53}$ aged 37, a gardener by occupation. He decided to save dozens of Jews in defiance of the occupier, who had sentenced them to death. Mr. W is devoted psychically and physically to his dearest lover, Miss 'Krysia' (thus the name of the bunker derived from the [Polish] word kryjówka [for a hideout]). [...] About a dozen future residents of 'Krysia' had lived for several weeks in a basement with a Volksdeutsch living above them. With their help, Mr. W. built an underground apartment with a kitchen and toilet, small

52 "Surveillance instruction" from the Minister of Internal Affairs' ordinance of 4 January 1924 regarding the organization of the investigative offices, as cited in: Misiuk, Pepłoński, Organizacja instytucji policyjnych..., p. 189.

${ }^{53}$ Ringelblum intentionally changed the personal details of Mieczysław Wolski. 
and uncomfortable, but safe, because it was in the middle of nowhere, far away from people's eyes." 54

Samuel Kassow, Ringelblum's biographer, writes: "In early March 1944, 'Krysia's run of good luck came to an end. According to three different sources, Wolski was denounced by his girlfriend after they had 'broken up'. The Jagurs ${ }^{55}$ claimed that 'Krysia' was denounced by 18-year-old Jan Łakiński, whom the Polish underground later executed as per a death sentence. On 7 March, the Germans and the Polish police came to Wolski's. They knew exactly where to look. One group rushed into the house, while the other ran to the garden and the greenhouse. Several Germans attacked Mieczysław, hurling abuse at him: "You damn Jewish lackey, you fancied hiding Jews? You'll pay for it, you fool!"56 Next, the Germans surrounded the entrance to the bunker and - firing into the air - threatened to "poison [all the Jews] like rats" if they did not voluntarily come out onto the surface. ${ }^{57}$ The Jews - after they had finally left the bunker were transported to the Pawiak prison. Several days later, they were all executed in the ghetto ruins. Gardener Mieczysław Wolski and his 15-year-old nephew Janusz Wysocki shared their fate.

The 'blue' policemen loyal to the patriotic underground provided a similar description of the bunker's discovery. A fragment of the entry dated 7 March 1944 in "Kronika wydarzeń" 58 prepared for the Office of the Delegate of the Government in Exile: "38 Jews hiding at Grójecka Street 81 in the buildings on gardener Wolski's farm were arrested, among them a child who was just a few days old. Those Jews had been hiding in the comfortably furnished basements of the greenhouse, where they had running water, a bathroom, and electricity. Gardener Wolski supplied them with food. The Jews had been staying in that shelter since 5 March 1943. They were rich people well known in the area of the $23^{\text {rd }}$ police station (baker Gitter, restaurateur Rawicz, Doctor Cendrowicz, and

${ }^{54}$ Emanuel Ringelblum, Stosunki polsko-żydowskie w czasie drugiej wojny światowej (Warsaw: Czytelnik, 1988), p. 160.

${ }^{55}$ Orna Jagur, Bunkier „Krysia” (Łódź: Oficyna Bibliofilów, 1997). The Jagurs (Orna and her husband Józef) moved out of the bunker shortly before its discovery.

${ }^{56}$ Samuel D. Kassow, Kto napisze naszq historię? Ostatni rozdział zagłady warszawskiego getta. Ukryte archiwum Emanuela Ringelbluma, trans. Grażyna Waluga, Olga Zienkiewicz (Warsaw: Amber, 2009), pp. 350-351 [original edition: Who Will Write Our History? Emanuel Ringelblum, the Warsaw Ghetto, and the Oyneg Shabes Archive, Bloomington: Indiana University Press, 2007].

${ }^{57}$ Today it is difficult to say how much truth there is the description of the police raid on Wolski's farm. The quotations come from the testimony given by Małgorzata Szadurska and Halina Michałecka (a sister of the killed gardener) at Yad Vashem in July 1988. However, according to the documents discussed later, it seems that the two women were not at home when the police arrived.

58 "Kronika wydarzeń" is discussed in more details by Dariusz Libionka in his article "Zapisy dotyczące Żydów w warszawskich kronikach policyjnych z lat 1942-1944," Zagłada Żydów. Studia i Materiały 10, vol. 2 (2010): 558-591. 
others). The German gendarmerie discovered them on the basis of a denunciation. The police from the $23^{\text {rd }}$ police station were also present during the liquidation of that shelter. The Jews were removed and deported with their belongings (fur coats, jewellery, four kilogrammes of gold, etc.), while the greenhouse and all the furnishings were destroyed with grenades and burned down. Wolski, his sister, and his nephew were arrested, and his private apartment was sealed."59

Less than six years after the discovery of the bunker and Ringelblum's death, new light was shed on that matter by materials of an investigation conducted by the communist Security Office with regard to a totally different case. The discovery of the hideout entered the investigators' sphere of interest actually by accident, on the margin of the investigation regarding predominantly the activity of the pre-war counterintelligence. The tracing of the Jews who were in hiding during the war constituted one of the secondary threads of the investigation, and this adds credibility to the findings regarding this matter.

On 26 January 1950, an anonymous militiaman from the People's Militia department in the Warsaw district of Ochota wrote a preliminary report. Although it contains mistakes (mostly in the chronology), it provides plenty of extremely important information. Particularly crucial are the findings regarding the liquidation of the bunker. The fact that they come from a period not very distant from the events described makes them twice as valuable to us. Consequently, let me quote extensive fragments of the report:

Today I conducted interrogations to learn more about the shelter in Ochota and find the witnesses, and I have established the following: after the arrival of the Germans in Warsaw and the establishment of the ghetto, Warsaw gardener Mieczysław Wolski, the owner of the house and extensive lot at Grójecka Street 81, built a secret underground shelter on his property, where more than 40 people of Jewish nationality were hiding friends of Wolski or their relatives; one known surname is Epsztein, a baker from Siewierska Street. Those were affluent people, who did not work anywhere and supported themselves in the shelter and paid their helper from their own funds. ${ }^{60}$ It remains unknown how the Germans discovered the hideout in 1943. It was liquidated. All the Jews in hiding were taken away by the Gestapo and none of them came back. Mieczysław Wolski and

${ }^{59}$ AAN, Delegatura Rządu na Kraj [Office of the Delegate of the Government in Exile], 202/II-44, „Kronika wydarzeń na terenie m.st. Warszawy od 1 sierpnia 1942 do 30 kwietnia 1944 r." [chronicle of events in the capital city of Warsaw from 1 August 1942 to 30 April 1944].

${ }^{60}$ It should be noted that neither in "Kronika wydarzeń," nor during the post-war investigations was it stated that Emanuel Ringelblum was in the hideout on Grójecka Street. Only "Kronika wydarzeń," which was quoted earlier, provided false information in the entry of 15 March 1944 about the arrest of Doctor Ringelblum as one of "those who looked after the bunker." 
his nephew Janusz Wolski ${ }^{61}$ were also arrested on that occasion, and they did not return either; they were probably executed. After the removal of the hiding Jews the shelter was destroyed with grenades and the house was set ablaze [...]. Among those still alive who were present at the liquidation of the bunker is Wolski's mother, who lives on Grójecka Street, and Wolski's sisters, who were elsewhere during the liquidation of the shelter. Wolski's relative Maria Czakajewska is also still alive; she lives on Siewierska Street 4, apartment 16. During the liquidation of the shelter the lot was surrounded by the German gendarmerie from the dormitory on Narutowicza Square; the liquidation was conducted by Gestapo functionaries and there were also individuals in plain clothes. [...] The liquidation lasted several hours. (-) illegible signature. ${ }^{62}$

The entry in "Kronika wydarzeń" clearly indicates that the raid on the 'Krysia' bunker was caused by a denunciation, which was usually the case. According to Kassow, it is possible that the discovery resulted from the denunciation made by the dumped woman or from Łakiński's information - by the way; these two versions are not necessarily mutually exclusive. But neither the witnesses nor the victims nor the militiaman who conducted the postwar investigation had any idea that the discovery of the 'Krysia' bunker and the death of its residents were predominantly directly connected to the large scale campaign of the Warsaw Sipo and particularly the special 'anti-Jewish' section established within the Polish Criminal Police.

For the employees of the Judenreferat of the Polish Criminal Police the turn of February and March 1944 was a period of increased activity. A handful of information on this topic is to be found in 'blue' policemen's reports collected from various Warsaw stations and then sent to the intelligence cells of the Office of the Delegate of the Government in Exile. The information from "Kronika wydarzen'" is credible when it pertains to the activity of the 'blue' policemen, relatively credible with regard to the Polish Kripo, and much less credible when it comes to determining the activity of the German police, including the Gestapo, where the 'blue' policemen who belonged to the underground had fewer moles. 29 February 1944 brought the arrest of Ludwik Landau, an employee of the Office of Information and Propaganda of the Home Army, but the circumstances of the arrest remain largely unknown. The next day the police apprehended Landau's wife and daughter, who committed suicide at the moment of the arrest. Julian Grobelny, the chairman of 'Żegota', was arrested on 1 March in Mińsk Mazowiecki after being denounced for his engagement in helping Jews. On 2 March, Kripo agents arrested Jan Jaworski, "a member of the committee for [aid to - J.G.] Jews," who came [[to] a 'candy store' on Mokotowska Street] to pay the ransom to the agents for the release of the Jews who had been apprehended earlier.

\footnotetext{
${ }^{61} \mathrm{~A}$ mistake in the report - Wolski's nephew, Janusz Wysocki, was arrested.

${ }^{62}$ AIPN, GK 317/248, pp. 67-67v.
} 
A notebook with a list of surnames and a fake ID for the surname of Zygadlewicz were found on Jaworski. ${ }^{63}$ On March 3, a day after his arrest, on Koźla Street Kripo agents apprehended a relatively large group of Jews in hiding, and four days later the 'Krysia' shelter was denounced. It remains unknown whether Jan Jaworski's capture contributed to Ringelblum's arrest, but the concurrence of two events is striking. ${ }^{64}$

The course of the operation can be relatively precisely recreated on the basis of the testimonies given by two participants in Ringelblum's arrest. Early in the morning of 7 March, as soon as the policemen reported for duty, SS-Untersturmführer Balhause raised an alarm in the section. After a short briefing, the policemen were ordered to get in the cars. "Balhause ordered everybody to go with him. We went by car to Grójecka Street, but I do not remember the number, it was between Narutowicza Square and the last trolleybus stop in the direction of Okęcie. When we arrived, it occurred that there were already about a dozen Germans from the Gestapo. We entered the estate through the gate. There were heated beds, which were surrounded by the Gestapo functionaries and us. As I realised on the spot, the gardener, who was the owner of the heated beds, had been apprehended, along with his teenage son. By order of one of the Germans, the gardener's son entered the bunker under the heated beds and explained to the Jews who were there that all resistance was futile and that they should all go out. The Jews left the bunker one by one; there were about 20 of them and they were apprehended by the Gestapo. Those Jews were of both sexes and of different ages, including children. After their apprehension, the Jews and the gardener and his son were transported to the Gestapo, while we returned to the Directorate." ${ }^{\prime 65}$

A different agent from the Tracing Kommando testified the following: "In the spring of 1944, by order of the Gestapo from the Kriegsfahndung section, I went to participate in the liquidation of the Jewish bunker. Two Germans, Ballhause, interpreter Bąk, and one more German [went there]. As for the Poles, Jan Puszyn went to the liquidation, and the Germans also had agents from other Brigades to help them liquidate the bunker." ${ }^{66}$ Interrogated after the war, the Polish policemen obviously tried to belittle their own involvement in those arrests: "I took part in the arrest of the Jews at Grójecka Street 81. The Germans were

${ }^{63}$ AAN, Delegatura Rządu na Kraj [Office of the Delegate of the Government in Exile], 202/ II-44, "Kronika wydarzeń" [chronicle of events], 2 March 1944. Both these surnames are probably false.

${ }^{64}$ Ibidem, "Kronika wydarzeń" [chronicle of events], 3 March 1944. According to the police report, as many as 30 Jews were arrested on Koźla Street, but I would approach this figure with caution as it does not find confirmation in other sources.

${ }^{65}$ AIPN, GK 317/248, Przesłuchanie Zygmunta Głowackiego [interrogation of Zygmunt Głowacki], 10 February 1950, pp. 33-34.

${ }^{66}$ Ibidem, Przesłuchanie Zygmunta Głowackiego [interrogation of Zygmunt Głowacki], 10 January 1950 , pp. 20-21. 
already there when we arrived. [...] It was only there that we learned that the Jews had been hiding there. I only saw them being escorted out by the Germans. After they had been taken away, the Germans told us that we could return to the Directorate, because they did not need us. Back then, I did not hear that the gardener had been taken away, neither did I see it. I learned about that only at the Directorate." Nevertheless, according to the policemen's testimonies, Kripo mobilised substantial resources for the raid on the 'Krysia' bunker, including contingents of 'blue' policemen from various Divisions. "As I recall [...] almost everybody from the section and a number of agents from the Directorate and other Divisions took [...] part in the liquidation of the bunker with the Jews on Grójecka Street in Ochota." ${ }^{67}$ Another testimony reads: "Each of us accompanied one Gestapo functionary. There was a shelter under the hotbeds on that estate. The Germans escorted some people out of that shelter. There were about a dozen of them. Those people were taken away by the Gestapo functionaries and transported somewhere by car. Where to? I do not know. We did nothing there. We were simply there." But it is difficult to believe that the policemen from the section 'for the eradication of Jews' were 'simply there' during that most important operation of their detachment.

As for the aftermath of that operation, one may once again refer to the report from the preliminary investigation, prepared in January 1950 by an anonymous militiaman from the People's Militia Department in the Ochota quarter of Warsaw. After interrogating the witnesses, he stated that after the Jews had been taken away "all movable property of Wolski and the hiding Jews was taken away by the $23^{\text {rd }}$ police station," ${ }^{\prime \prime}$ while "the [worthless] rags left behind by the police were looted by the local inhabitants." The final sentences of the report read: "All residents of Wolski's house vanished during the liquidation of the shelter, taking with them the most valuable items, undisturbed in their flight by the uniformed police from the $23^{\text {rd }}$ station, which cordoned off Grójecka Street, where crowds of local inhabitants had gathered." ${ }^{69}$ As I have already mentioned, the issue of the discovery of the 'Krysia' bunker and the murder of its residents was not really of great interest to the People's Militia. The best proof here is the fact that only gardener Wolski's mother was interrogated from among the living witnesses of the shelter's liquidation mentioned in the report. ${ }^{70}$

The discovery of the bunker on Grójecka Street must have echoed far and wide in the management of the Warsaw District police, because already on the

${ }^{67}$ Ibidem, Zeznanie Władysława Nowińskiego [testimony of Władysław Nowiński], 13 February 1950 , pp. $45-45 \mathrm{v}$.

${ }^{68}$ At that time the $23^{\text {rd }}$ station of the Polish Police was in charge of the area of Grójecka, Kopińska, and Kaliska streets.

${ }^{69}$ AIPN, GK 317/248, pp. 67-67v.

${ }^{70}$ Ibidem, Zeznanie świadka Małgorzaty Wolskiej [testimony of witness Małgorzata Wolska], pp. 62-62v. In her short, two-page testimony, the mother of the murdered gardener stated that two Germans and two Polish policemen came to search her home. 
same day the German authorities applied for financial prizes for 15 Kripo clerks for their loyalty and zealous work. Although one cannot be completely certain that those prizes were connected with the discovery of the 'Krysia' bunker, it seems unlikely that the concurrence of those two events was coincidental. ${ }^{71}$

The said operation was not the last 'success' of the Warsaw Kripo. The entry of 15 March in the already quoted "Kronika wydarzeń" informs of the arrest of more people connected with the residents of the bunker on Grójecka Street apprehended a week earlier. On 22 March, the police discovered another hideout - that time at Orla Street 12; at the turn of March and April, the Warsaw Kripo took part in blockades in Żoliborz that led to the apprehension of 40 Jews; and on 2 April a detachment commanded by Balhause conducted new arrests - that time in restaurants.

\section{'Jewish gold'}

Having learned about certain elements of the activity of the Kriegsfahndungskommando, one might inquire about the motivation of its individual employees. On the one hand, the police discipline and obedience to orders undoubtedly played a significant role in assuring an appropriate level of cooperation on the part of the Kommando's members. But on the other hand, at least in certain instances, the decision to become Balhause's subordinate was made by the candidates of their own volition. However, it does not seem that the ideology was an important factor. Anti-Semitic prejudice might have facilitated making a decision to join the catchers (certainly earlier aversion to Jews facilitated the 'work' itself), but the main motivation was the willingness to make a quick profit. ${ }^{72}$

According to a female employee of the Criminal Police Directorate, "that entire section dealt with eradicating the Jews and looting their property."73 Other sources confirm the conviction that the desire to loot Jewish property was an important factor that motivated the policemen. By the way, that desire to obtain 'Jewish gold' was not an exclusive characteristic of the employees of the Jewish desk, and it seems that it was equally applicable to policemen from other divisions of the Polish Criminal Police in Warsaw.

According to reports of the AK intelligence, at the end of autumn of 1942 and in the winter of 1943, representatives of a special commission of the Warsaw Criminal Police appeared in the ghetto, which had become deserted after the

${ }^{71}$ AAN, Delegatura Rządu na Kraj [Office of the Delegate of the Government in Exile], 202/ II-44, "Kronika wydarzeń" [chronicle of events], 15 March 1944.

${ }^{72}$ AIPN, GK 317/248, Przesłuchanie Marii Dzięgielewskiej [interrogation of Maria Dzięgielewska], pp. 91-91v: "I suspect that [both those policemen] were transferred upon their own request as the brigade commander could not have transferred them."

${ }^{73}$ AIPN, GK 317/248, Przesłuchanie Marii Dzięgielewskiej [interrogation of Maria Dzięgielewska], 3 January 1950, p. 52v. 
great deportation campaign. Their task was to allocate the vacated apartments to the criminal policemen. Members of the commission included policemen Mikołaj Gruca, ${ }^{74}$ Tadeusz Wojtulski, and Edward Siepradzki. ${ }^{75}$ The commission was headed by former legionary and Cross of Independence knight Second Lieutenant Michał Olczyk, ${ }^{76}$ the same who at the beginning of the occupation was the director of Division II of the Polish Criminal Police (that is, the 'theft' one). A fragment of the Home Army report: "Using an official pass, Olczyk entered all the apartments in the residential buildings assigned to the Kripo employees and took not only the more valuable items, such as book collections, paintings, antiques, and stamp collections, but also almost all furniture, gas burners, etc. He has already sold some of those items, and he is gradually selling the rest. In search of gold and foreign currency, he smashed walls and dismantled stoves, as a result of which he devastated almost all of the apartments [...]." The entrepreneurial policeman developed a large-scale activity: he hired special crews to demolish the apartments, he sold Jewish workshops located on 'his' territory along with their supplies of raw materials, and eventually he came into conflict with the Polish appointed administrators who managed the 'post-Jewish property' by order of the Germans. The appointed administrators had to back down, because Lieutenant Olczyk threatened them with the Security Police. According to the information collected by 'Pleban' (codename of Bolesław Kozubowski, the chief of the counterintelligence of the Department II of the Polish General Staff of the Warsaw District AK Command), Olczyk might have threatened not only a Sipo intervention, but he might as well have made references to his connections in the underground because - according to the underground's findings - he was a member of the 'Odwet' organisation [Polish for 'revenge']. ${ }^{77}$

Returning to the Kriegsfahndungskommando, the arrested Jews' property was usually delivered to the section's offices, where the employees sorted the loot obtained during the searches. The daintier morsels were allocated to the Germans, but the Polish agents had no reason to complain. A fragment of the testimony of a former employee of the Jewish desk: "As for the post-Jewish property, only the more valuable items were taken, and, after being transported to the section, they were sorted by the Germans, who appropriated most of those things and the more valuable items, while the rest was distributed among

\footnotetext{
${ }^{74}$ Policeman Gruca worked in the Main Administrative Office Warsaw Criminal Police Directorate (AIPN, 0423/3402, p. 252).

${ }^{75}$ Before the war policeman Siepradzki worked in the ethnic minorities brigade of the political section of the Investigation Office, and during the occupation he served in the 'theft' brigade. In his own biography written after the war he stated that during his employment in Kripo he was an active member of the underground, 'Wiciarz' organization, and the Peasants' Party (Stronnictwo Ludowe), where his codenames were 'Prałat' and 'Wolski' (AIPN, 0423/4902, p. 13).

${ }^{76}$ AIPN, 0423/4889, Meldunek bez daty [undated report], p. 8.

${ }^{77}$ AIPN, 0423/4889, Raport „Plebana” ['Pleban's report], no date, p. 9.
} 
the Polish employees. As for me, I received linen two or three times. When money was found on the apprehended Jews, it was kept by director Ballhause, and after some time he paid out certain sums to the Polish agents in the form of bonuses for good performance. I also received several such bonuses: as I can recall, it was 2,000 zlotys, 1,000 zlotys, 800 zlotys, etc. - usually sums around 1,000 zlotys. I also sold the linen from the post-Jewish property that I had received, and I obtained approx. 2,000 zlotys for it. On two occasions I took part in collecting items from purportedly post-Jewish apartments." ${ }^{78}$ The Jewish apartments assigned to the Kommando members were also not to be despised. In the autumn of 1943, one of such apartments, located at Solna Street 16, was assigned to agent Nowiński. Aside from the means obtained authorised or guaranteed by the German supervisors, there were also profits derived from the Polish agents' independent activity. In this case it is difficult to say whether or how often they attempted blackmail (for the border between a Kripo agent and a szmalcownik was at times elusive), but the files include surviving testimonies of Henryk Wileński, a relatively wealthy Polish entrepreneur, who was arrested by one of Balhause's subordinates. The method of obtaining additional profits was simple: after apprehending an individual, his or her family was offered the opportunity to buy the victim out of gaol for an appropriate sum. The sums were often exorbitant, around a few dozen or even a few hundred thousand zlotys, but the prospect of the detainee's deportation to a camp or execution had a mobilising effect on the families. ${ }^{79}$

Was the Kreigsfahndungskommando the only unit established by the German criminal police in Warsaw to pursue Jews? ${ }^{80}$ It is highly unlikely as the archival materials contain scattered testimonies, which seem to suggest that similar groups did exist. According to a Kripo employee, such a cell was most probably a part of Division VI of the Polish Criminal Police. "I learnt about that section by accident in 1941 or 1942," testified one of the Warsaw criminal policemen, "when I entered the gaol with a detainee, by the entrance to the gaol I met Citizen Michał Wodnicki, whom I know personally and who live[d?] at Pańska Street 100 in the same building as I lived in at that time. When I asked him what he was doing there, Wodnicki replied that he had been apprehended on suspicion of sheltering people of Jewish nationality or keeping Jewish property and that the investigation with regard to his case was conducted by a special section that pursued Jews, whose office was located on the first floor [on Daniłowiczowska

${ }^{78}$ AIPN, GK 317/248, Przesłuchanie Zygmunta Głowackiego [interrogation of Zygmunt Głowacki], 11 February 1950, pp. 35-37.

${ }^{79}$ Ibidem, Zeznanie Władysława Nowińskiego [testimony of Władysław Nowiński], 13 February 1950, pp. 60-60v; ibidem, Zeznanie Henryka Wileńskiego [Henryk Wileński's testimony], pp. $92 \mathrm{v}-93$.

${ }^{80}$ Of course, I do not mention here the more thoroughly researched Judenreferat of the Gestapo, that is, Section IV B directed by SS-Untersturmführer Karl Brandt and seated on Aleja Szucha Street. 
Street - J.G.]. Being familiar with the layout, I concluded that the section was a part of Division VI." ${ }^{\prime 1}$

A similar role was purportedly played by a team consisting of about a dozen Kripo agents lead by SS-Hauptsturmführer Georg Richter, one of the heads of the Warsaw Criminal Police Directorate. Richter's group, which similarly to Balhause's group was established in the autumn of 1943, and was to combat the Polish underground, expand its spy ring in the criminal milieus, and pursue Jews in hiding. ${ }^{82}$ In his diary entry dated 21 December 1943, Ludwik Landau alluded to that group's activity: "there was another incident today that might serve as a pretext for an official murder - a German was killed on Długa Street. He was wearing plain clothes, but the rumour has it that he was not only a policeman but a 'chief of police', but this is certainly untrue. It remains unknown whether that has anything to do with the tanks and numerous patrols on the streets today, which as always stop the pedestrians, check their IDs, and frisk them." ${ }^{83}$ That time the rumour was not unfounded: the policeman killed on Długa Street was a Warsaw Volksdeutsch, Karol Bartl, Kripo Sergeant, before the war a policeman from the Investigation Office and during the war Richter's right hand. ${ }^{84}$ One Kripo employee, Józef Osipiak, was killed together with Bartl and another one, Władysław Więckowski, was wounded. ${ }^{85}$ According to the Home Army's intelligence, Więckowski often worked with Marian Szwed and also "captured Jews and Poles who sheltered Jews." ${ }^{86}$ The execution on Długa Street was, as it seems, directly connected with the activity of the said special detachment subordinate to the Criminal Police Directorate. Bartl's liquidation most probably testified to the danger, which the operations of the new Kripo unit posed to the underground, as it is more than doubtful that the policeman's execution was conducted solely in connection to the tracing of the Jews in hiding. On the contrary, the Home Army intelligence's reports that survived in the archives seem to suggest that Richter's people were interested predominantly in the Polish underground organisations. ${ }^{87}$

${ }^{81}$ AIPN, GK 317/248, Przesłuchanie Zygmunta Głowackiego [interrogation of Zygmunt Głowacki], 25 January 1950, pp. 25-28; AIPN, GK 317/247, Protokół rozprawy głównej [minutes of the main hearing], p. 88v.

${ }^{82}$ Hempel, Pogrobowcy klęski..., pp. 204-205.

${ }^{83}$ Ludwik Landau, Kronika lat wojny i okupacji, vol. 3: Lipiec 1943-luty 1944 (Warsaw: PWN, 1963), p. 494.

${ }^{84}$ Władysław Bartoszewski, 1859 dni Warszawy (Cracow: Znak, 1974), p. 489.

${ }^{85}$ AIPN, 0423/4999, Meldunki z kartoteki AK [reports from the Home Army files], p. 16.

${ }^{86}$ Ibidem, Raporty „Hanny” z 23 X i 11 XI 1943 r. ['Hanna's reports of 23 October and 11 November 1943], p. 15/1, 15/2. Marian Szwed died by accident during the liquidation operation on 15 April 1944 prepared by the AK Directorate of Diversion (Kierownictwo Dywersji, Kedyw). Its actual target was Jerzy Tabęcki, codename 'Lasso'.

${ }^{87}$ For obvious reasons the Home Army intelligence devoted much more attention to the 'WBB operations' [Widerstandsbewegungbekämpfung - fighting the underground] than to any activity aimed at pursuing Jews. 
One of the Kripo employees from Richter's operational group identified by the Home Army intelligence was a Władysław Putyński (born in 1924). The Home Army agents who carried out the surveillance unanimously agreed that Putyński acted for the benefit of the Germans and tried to keep the underground under surveillance. By contrast, Putyński's race was disputable. The initial reports of the Home Army intelligence (prepared between April and September 1943) stressed his Jewish origin. ${ }^{88}$ Feliks Wiązowski, Tadeusz Różycki, and Alfred Klauzal, who kept him under surveillance, were convinced of the informer's Jewish origin. But the later reports of 993/P (Home Army counterintelligence unit, where policemen from the Polish Police and the Polish Criminal Police played the key role) prepared in June 1944 identified Putyński as an 'Aryan': "Rom[an] Cath[olic], Polish cit[izen], employee of Division I of Kripo." ${ }^{89}$ All the reports mention only the surveillance of the underground and not the persecution of the Jews.

A question arises: Did Warsaw, with its relatively large number of Jews in hiding, constitute an exception in the German strategy of hunting for Jews? Were the Kriegsfahndungskommando's counterparts established in other cities in the General Government: in Kraków, Lublin, or Radom? ${ }^{90}$ At the current stage of research it is impossible to answer this question, but there is no doubt that from the autumn of 1942 the gendarmerie and the 'blue' police had established a whole range of detachments for special tasks, which basically focused on pursuing and murdering Jews. I am referring here to Rollkommandos or Jagdkommandos, which operated predominantly in the countryside in all Districts of the General Government and usually consisted of one or two German gendarmes and about a dozen Polish policemen. ${ }^{91}$

As for Kripo's activity in the cities of the General Government, there is a handful of information from the District of Galicia, predominantly from Lvov. In August 1941, after the District had become a part of the General Government, the Germans began to organise the police force in Lvov, same as they had had in all four remaining district capitals. In Galicia, as opposed to the ethnically Polish lands, instead of the 'blue' police, the Germans established the Ukrainian police (Ukrainian Auxiliary Police - Ukrainische Hilfspolizei), known as the

${ }^{88}$ Stefan Ryś 'Józef' - deputy director of the Security and Counterintelligence Section of Department II of the Home Army High Command (Wydział Bezpieczeństwa i Kontrwywiadu Oddziału II Komendy Głównej AK). He established the identity of the agents who kept Putyński under surveillance in 1943: 'I-60' was Feliks Wiązowski, 'I.73a' was Tadeusz Różycki, and 'Mecenas' and 'Knajpa' were codenames of Alfred Klauzal, the Warsaw Area AK counterintelligence chief (AIPN, 0423/4492, pp. 4-5).

${ }^{89}$ Ibidem, p. 2.

${ }^{90} \mathrm{~A}$ handful of information about the tracing of Jews by the Polish policemen from the Lvov Kripo can be found in AIPN, GK 317/616.

${ }^{91}$ Jan Grabowski, Hunt for the Jews. Betrayal and Murder in German-Occupied Poland (Bloomington: Indiana University Press, 2013), pp. 101-121. 
'black' police from the color of its uniforms. Even though the Ukrainian police had six Divisions in Lvov and stations scattered throughout the District, the level represented by its employees left much to be desired: there were few Ukrainians in the prewar Polish police, and consequently, the men recruited to the Ukrainian police during the war often did not meet basic professional and moral criteria. ${ }^{92}$ The candidates, often illiterate, were sometimes recruited in the villages near Lvov. Consequently, during the occupation, a rhyme in a Lvov dialect circulated in the city, concerning peasant origins of many policemen. ${ }^{93}$

Those personnel shortages could not be solved with the use of the Ukrainian policemen trained in police schools in the General Government prior to the invasion of the Soviet Union..$^{94}$ While Ukrainians constituted the majority in the uniformed police, Poles were definitely dominant in the criminal police. Most of those agents subordinate to the newly-established Criminal Police Directorate (DPK Lemberg) came from the prewar personnel of the Investigation Office.

Most information on the topic of the activity of the Lvov Kripo is to be found in the files of the local Special Court (Sondergericht Lemberg). According to these materials, the activity of the Lvov criminal policemen manifested a certain Galician peculiarity: the local Kripo conducted independent investigations into 'Jewish' cases until the end of the occupation. This is all the more important as from the moment of the arrest until the execution of the apprehended Jews, usually murdered in the camp on Janowska, Kripo was fully engaged in the course of the investigation. Furthermore, as opposed to Warsaw Criminal Police Directorate, which after arresting the Jews handed the cases over to the Gestapo, the Polish policemen in Lvov conducted independent investigations against the Poles and the Ukrainians accused of helping Jews. ${ }^{95}$

While the apprehension of the Jews hiding in Lvov was the duty of the employees of all Criminal Police Directorate Divisions, Division III received special prerogatives in that respect. ${ }^{96}$ For example, one may quote the description

${ }^{92}$ Christoph Mick, "Incompatible Experiences: Poles, Ukrainians and Jews in Lviv under Soviet and German Occupation, 1939-44," Journal of Contemporary History vol. 46, 2 (2011), p. 351.

${ }^{93}$ Jak ja buł na seli, tu ja pas krowy//A teper ja u Lwowi pan posterunkowyj//Jak ja buł na seli, tu ja pasał byki//A teper ja u Lwowi policaj wełykij.

${ }^{94}$ Finder, Prusin, “Collaboration in Eastern Galicia...," pp. 95-118.

${ }^{95}$ In 1944 in Lvov, the Jewish cases were also investigated by the local SD, see DALO, Sondergericht Lemberg [Special Court in Lvov], file 1279, Raport z dochodzeń [report on investigations], 25 May 1944, p. 14.

${ }^{96}$ The surviving files of the Lvov Special Court make it possible to recreate at least a fragmentary list of the Kripo policemen who tracked down Jews in that city. According to the surviving interrogation transcripts and the internal correspondence, Division III's staff during 1943-1944 included: Senior Sergeant Mikołaj Czernik, Karol Krajewski (Kriminal Zugführer), Zygmunt Głowacki (Kriminal Zugführer), Robakowski (Kriminal Feldwachmeister), Józef Wawrzyniak (Kriminal Feldwachmeister), Grabow (Kriminal Sekretär), Schiller [Schilling] (Kriminal Sekretär), Stroszyński (?) (interpreter). 
of an operation conducted by the local criminal police. On 16 June 1944, Platoon Leader Michalski and two other policemen from Division II of the Criminal Police in Lvov discovered a Jewish hideout: "I learned in confidence that there were Jews at Roman Dąbrowski's, domiciled in Lvov at Łyczakowska Street 19, apartment 7. Consequently, Corporal Makohon, Corporal Bielc, and I went to that apartment, where during the search we discovered a hidden shelter masked with wallpaper, where five Jews were hiding. The Jews were escorted to the local Directorate." 97 There, at the Criminal Police Directorate, the case was handed over to the policemen from Division III, who took over the investigation. It seems that at least from 1943 all 'Jewish cases' (mostly investigations regarding instances of sheltering) were automatically transferred to Division III for further processing. Aside from Kripo, as in other Districts of the General Government, the Lvov Gestapo (KdS, Section IV B 4) also dealt with the Jewish cases. In Galicia, it had a few outposts (Aussenstellen). During the investigations the policemen from Kripo's Division III gave particular attention to searching for Jewish valuables - they even dug up the basements of the buildings where the Jews had been hiding. ${ }^{98}$ Similarly to their Warsaw colleagues, the Polish agents of the Lvov Kripo relied to a large extent on information from informers. At the turn of 1943 and 1944, there were even official rates for rewarding the informers: the Polish Criminal Police paid a thousand zlotys for each captured Jew. ${ }^{99}$

\section{The End of the Kriegsfahndung Section}

The Kriegsfahndungkommando remained active until the outbreak of the Warsaw Uprising. Agent Zygmunt Głowacki deserted from Kripo as late as at the turn of June and July 1944. At the same time he obtained a falsified Kenkarte issued to Euzebiusz Piąty: "Let me add, that that surname was written without consulting with me," Głowacki testified during the postwar investigation. ${ }^{100} \mathrm{On}$ 8 August 194, other policemen from the section retreated with the Germans from Warsaw, which was overtaken by the uprising, to Sochaczew and later, in January 1945, to Poznań. Most of them vanished without a trace.

${ }^{97}$ DALO, Sondergericht Lemberg, file 847, Raport [report], 16 June 1944, p. 2.

${ }^{98}$ DALO, Sondergericht Lemberg, file 1279, III Komisariat Lemberg [Division III in Lvov], 16 June 1944, p. 20.

99 “Die für eine Judenergreifung ausgesetzen $1000 \mathrm{zł}$ sind an den V-Mann 'Messer' des Kdos. auszubezahlen [Agent 'Messer' shall be paid a thousand zlotys for capturing a Jew]" (Ibidem, Przesłuchanie dr. Davida Ehrlichhofa [Doctor David Ehrlichhof's interrogation], p. 12); "Für die Ergreifung des Juden kommt der Pole Mokołaj Kostiuk, Werbeinstitut Galizien, Marienpl. 2 in Frage, dem auch die Belohnung zufällt [Mikołaj Kostiuk, a Pole who works in the Werbeinstitut, Marienplatz 2, contributed to the capture of a Jew and for this he shall be remunerated]" (DALO, Sondergericht Lemberg, file 1227, Raport [report], 23 May 1944, p. 3).

${ }^{100}$ AIPN, GK 317/248, Przesłuchanie Zygmunta Głowackiego [interrogation of Zygmunt Głowacki], 1 February 1950, pp. 30-31. 
However, some questions remain: Were the forms of the anti-Jewish operation described in this text the only ones conducted by Kripo? To what extent and how often did the Polish policemen from Kripo act - similarly to their colleagues in blue uniforms - independently and without the knowledge of their German superiors? Moreover, little is known about the role of the criminal policemen during the liquidation of ghettos and their contacts with the underground. All these issues await in-depth research.

As opposed to the Gestapo or SD employees, whose shared guilt was obvious, the policemen from Kripo effectively defended themselves after the war, bandying the argument that the institution where they worked had an 'apolitical' character. Edward Podgórniak from Kripo in Węgrów testified the following: "During the occupation, the criminal police [...] was obliged to detect and combat crime: manslaughters, theft, and so on. Moreover, we were ordered to help the uniformed police. We did not deal with political crimes, because we were forbidden to do so, as it was the responsibility of the Gestapo." ${ }^{101} \mathrm{He}$ then continued: "The criminal police did not participate in the operations organised specifically to capture people of Jewish origin. Personally, I took part in three operations, but their objective was to prevent banditry. Every day the individual police stations in the municipalities filed reports on assaults and robberies, on which basis they estimated the intensity of criminality in the individual areas. The German gendarmerie organised the operations in cooperation with the Gestapo. Usually we would surround a forest and search it. The criminal police did participate in those operations because we were the ones particularly interested in banditry."102

The German and the Polish employees of Kripo defended themselves in the same way, that is, by stressing their achievements in combating common crime and shifting the responsibility for the persecution of Poles (and Jews) onto the employees of other divisions of Sipo, usually the Gestapo. Commissioner Tewes, who had worked in the Warsaw Kripo, stressed the professional conduct of the German and Polish criminal policemen and their being total apolitical, which manifested itself in their combating common crime. ${ }^{103}$ SS-Rottenführer Hans Gundlach, the Criminal Commissioner delegated to the Osteinsatz in the Kraków and Rzeszów Kripo, testified the following after the war: "[A]t that time, together with the Polish police, I participated in tackling banditry [...] it was not [my emphasis - J.G.] about political crimes, but ordinary criminal cases. In early 1940 I was delegated to Kraków to the position of the Criminal Commissioner.

${ }^{101}$ AIPN, GK 318/131, Zeznanie Edwarda Podgórniaka z 20 II 1950 r. [Edward Podgórniak's testimony of 20 February 1950], p. 422.

102 Ibidem, p. 423.

${ }^{103}$ AIPN, GK 164/3754, Protokół przesłuchania Tewesa przez angielskie władze okupacyjne w Niemczech [typescript of the interrogation of Tewes by the English occupation authorities in Germany], 23 August 1946. 
I stayed there until Christmas 1940. Both in Rzeszów and Kraków I was formally subordinate to the Chief of Kripo in Poland, Oberregierungsrat Schräpel. In the summer of 1940, another higher rank Kripo officer, Criminal Director Fleischer, arrived in Kraków from Berlin, and he was my immediate superior. Our duties in Kraków were ordinary duties of every police force unengaged in political matters. Within their scope we investigated criminal cases under the penal code (theft, assaults and robberies, murders, fraud, etc.) as long as there were no political motives. The same as all other policemen from Kripo, I never participated in investigations of a political character, such as, forced deportations, liquidations of Jewish ghettoes, political interrogations, or deportations of Polish labourers to the Reich. The Gestapo dealt with all that." ${ }^{104}$ In the case of Commissioner Gundlach that rather obvious defence strategy did bring the desired effect, as he was exonerated from the suspicions and released from the American internment camp. But Commissioner Hans Gundlach forgot to mention in his testimony that in December 1940 he was arrested by the Kraków Gestapo on charges of stealing "Jewish gold" from Kripo's police hideout and sentenced by the SS court in Berlin to 14 months in prison. ${ }^{105}$

Emanuel Ringelblum died with his son and wife, murdered a week after being arrested in the ruins of the former ghetto, probably in the same place where the Museum of the History of Polish Jews stands today. And what was the fate of the Polish policemen co-responsible for his capture? Zygmunt Głowacki and Władysław Nowiński were arrested (during an investigation conducted with regard to a different case) in January 1950. On 14 July that year, the Warsaw Appellate Court found those two former employees of the 'Jewish desk' guilty as charged. Głowacki and Nowiński received prison sentences: ten and seven years respectively. Both the public prosecution service and the two sentenced policemen appealed against the sentence. During the appellate hearing on 16 February 1951 the Supreme Court upheld Głowacki's sentence and reduced Nowiński's sentence to four years' imprisonment. Nowiński was soon released, while Głowacki left prison immediately after the 1955 amnesty. The other members of the Kriegsfahndungskommando never stood trial.

Translated by Anna Brzostowska

\footnotetext{
Abstract

During the occupation, the Germans re-organised the Polish police forces. The regular police, henceforth known as 'blue police', resumed its duties under the supervision

${ }^{104}$ AIPN, GK 164/2928, Protokół przesłuchania oskarżonego, w obozie internowania cywilów nr 2 Sandbostel [typescript of the interrogation of the defendant in civilians' internment camp No. 2 in Sandbostel], 13 August 1946, p. 1.

105 Ibidem, Protokół z 22 VIII 1946 r. [typescript of 22 August 1946], p. 4. Gundlach served ten months, after which he was released on parole and then enlisted as a rank-and-file soldier for the SS police division.
} 
of the German Order Police [Orpo - Ordnungspolizei], while the secret police, now called Polish Criminal Police, was incorporated into the German Kriminalpolizei, or Kripo. Although there have been no historical studies of the Polish Kripo, it seems that this organisation played an essential role in tracking down and killing the Jews in hiding. This article, which largely draws on previously unknown archival material, focuses on the Warsaw section of the Polish Criminal Police. More specifically, it discusses the creation and the role of several specialised units, created for the sole reason of hunting down the Jews in hiding, in Warsaw, during the 1943-1944 period. The units have been responsible, among others, for the detection and arrest of Emanuel Ringelblum, the founder of "Oneg Shabbat", the underground archive of the Warsaw ghetto.

\section{Key words}

Jews, Holocaust, hiding, Polish Police, Poland, Emanuel Ringelblum 